\title{
A Customer Satisfaction in Mobile Telecom Industry in Chennai
}

\author{
Gowtham Ashirvad Kumar, A. Ravi Kumar, J Pavithra
}

\begin{abstract}
This examination explores the relationship among consumer loyalty, client trust, exchanging cost and client dependability in portable telecom industry in Chennai.The media transmission industry in Chennai has created to be exceptionally focused, as various Telecom organizations bump for the consideration of supporters. One of the key difficulties standing up to these Telecommunication organizations is the means by which they deal with their administration quality, which holds an incredible significance to consumer loyalty. Broadcast communications organizations likewise discuss their clients being their most significant resources, much the same as organizations in different business areas. Along these lines it is vital in the present business situation to comprehend the way that the possibility of client's being an organization's most significant resources isn't only an administration hypothesis yet is an extremely vital financial certainty. As the cell business in India is one of the quickest developing areas, it is significant and intriguing to investigate the drivers of consumer loyalty in this industry.The components identified with installments and reserve funds, (for example, offers, leases, and charges) are the most noteworthy in deciding fulfillment, maintenance, and probability of changing starting with one portable supplier then onto the next. Then again, intercommunication factors, (for example, client administration, neighborly representatives, and easy to use sites) were observed to be the least noteworthy. A critical positive relationship was found among fulfillment and maintenance while a poor affiliation was seen between fulfillment/maintenance and unwaveringness.
\end{abstract}

Keywords: Customer satisfaction, Customer trust, Customer loyalty, Customer retention. Switching cost, Telecommunication, Service quality.

\section{INTRODUCTION}

The development pace of portable media transmission administration market is amazing in Chennai for as far back as couple of years[1],[3],[5]. There is a colossal development for portable administration clients with a predictable increment of clients for past few years. Mobile media transmission administration market is winding up progressively focused with the expansion in the quantity of cell phone administration clients just as the quantity of cell phone specialist co-ops. Reasonable challenge powers the focused portable specialist co-ops to advance, improve and

Revised Manuscript Received on July 22, 2019.

Gowtham Ashirvad Kumar, Department of MBA, Bharath Institute of Higher Education and Research, Chennai, India.

Email: chakravins@gmail.com

Dr. A. Ravi Kumar, Department of THM, Bharath Institute of Higher Education and Research, Chennai, India.

Email: ravikumar.th@bharathuniv.ac.in

Ms J Pavithra, Department of MBA, Bharath Institute of Higher Education and Research, Chennai, India.

Email: pavithralect@yahoo.com separate their items and administrations so as to win first-time versatile clients, to draw clients from their adversaries, and to hold their present clients[2],[4],[6]. As an outcome, consumer loyalty has developed as a noteworthy maintenance factor.In a focused economy the client chooses the achievement or disappointment of a business either by purchasing or not purchasing. The thought underlines the idea of "shopper's power". The cutting edge promoting idea has perceived this privilege and this is reflected in understood articulations like "buyer is the lord"[7],[9],[11]. It would essentially put out best item and administrations on the planet and value it underneath expense. There by it would make generous consumer loyalty however it would likewise be bankrupt. Consumer loyalty is an individual's sentiment of delight or disillusionment coming about because of looking at an item seen exhibition in connection to his or her experience.

\section{NEED FOR THE STUDY}

The exponential development of portable media transmission administration showcase in setting of cell administration clients has uplifted the requirement for examination of consumer loyalty, trust and changing expense to display client faithfulness[8],[10],[12]. Furthermore, the focused versatile media transmission administration market is setting out toward development organize; where a mobile phone administration firm not just needs to fulfill its clients better with an upper hand just as it needs to hold its clients. Up until this point[31],[33], be that as it may, there has been little exchange about the assurance of reality that consumer loyalty and client trust are indicators of client faithfulness in versatile media transmission administration market of Chennai. This paper looks to address client trust as arbiter in deciding the connection between consumer loyalty and client unwaveringness. Moreover, this examination gives a record of the directing job of exchanging cost on relationship of consumer loyalty with client reliability in portable media transmission administration market of Chennai. In conclusion, this investigation is to exhibit ramifications of the system for the business with the goal that the cell phone administration giving firms can be profited through understanding the indicators of client faithfulness[13], [15],[17].

\section{B. Objectives}

Primary Objective

- To investigate consumer loyalty with administration conveyance of Mobile Telecommunication Networks in Chennai.

Secondary Objective 
- To measure the general consumer loyalty with the administrations conveyed by Mobile Telecommunication Networks in Chennai.

- To measure consumer loyalty with Reliability of administration quality in Mobile Telecommunication Networks in Chennai.

- To inspect exchanging goals among clients of Mobile Telecommunication Networks in Chennai.

\section{Customer Satisfaction}

In the present aggressive and dynamic market, the term consumer loyalty has gotten much consideration and enthusiasm among researchers and experts. This maybe can be followed to its significance as a key component of business system, and objective for all business exercises (Anderson et al, 1994).

There are two fundamental definitional approaches to manage the examination of buyer dependability (Parker and Mathew, 2001). The principle system describes shopper reliability therefore while the resulting approach considers it to be a methodology. It is at any rate basic to observe that these two systems are not absolutely disconnected but instead comparing, as one every now and again depends upon the other. As a method, customer reliability is portrayed as an appraisal between what was gotten and what was ordinary (Johnson, 2001; Gustafsson, Johnson and Roos, 2005), focusing on the perceptual, evaluative and mental strategies that add to buyer devotion (Vavra, 1997).

The procedure meanings of fulfillment in any case, focus on the forerunners of fulfillment instead of fulfillment itself (Parker and Mathews, 2001). The result approach of the consumer loyalty is characterized as the end-state fulfillment coming about because of the experience of utilization. This is a post-utilization state and can be a result that happens without looking at desires (Oliver, 1996). Moreover, Parker and Mathews (2001) communicated that consideration has been centered around the idea of fulfillment of the result approach which include: feeling, satisfaction and state[14],[16], [18].

Truly, flipping through the writing on fulfillment demonstrates that fulfillment itself is a perplexing idea and hard to consistently characterize and precisely measure.

\section{RESEARCH DESIGN}

Research configuration is basically the structure for the examination that helps investigation and accumulation of information, clear research configuration is followed in the examination[19],[21],[23]. Essential information was gathered through an organized survey which is set up based on targets of the investigation and auxiliary information is gathered from books, sites and diaries.

\section{RESULTS}

The accompanying discoveries depend on the examination and understandings produced using the essential data.Data were broke down for the entire example just as for various classifications of sexual orientation and age. Sexual orientation and age contrast examination demonstrated no discernible distinction from the general example investigation[20],[22],[24].

- $27 \%$ of the respondents are having an expectation to switch over to an alternate specialist organization.

- Merely a $45 \%$ of respondents communicated their ability to switch over to an alternate supplier in the event that they have a superior offer.

\section{DISCUSSIONS}

With the expanded challenge in the Chennai Telecommunications industry, holding clients is one noteworthy methodology that the organizations must receive to stay productive. With the presentation of Mobile Number Portability [25],[27],[29] (MNP) which enables supporters of port to a superior specialist co-op while keeping up the current versatile number, holding clients ought to be a shrewd choice than pulling in new clients since it is more affordable. In this examination, the real determinants of exchanging are observed to be factors, for example, "had a superior offer", "disappointed with the charges connected by the past supplier", and "the new supplier has more grounded sign inclusion." [26],[28],[30]In request to lessen the beat rate, portable specialist organizations need to keep their clients fulfilled.

\section{CONCLUSION}

After directing this examination, new discoveries were found. Be that as it may, the principle goals of this examination were likewise accomplished. The exploration had the option to decide the connection between administration quality/conveyance and consumer loyalty, and exchanging goal among cell phone clients in Chennai. In view of the investigation led to test the different connections, each of the three traits had a critical association with consumer loyalty. Administration conveyance and dependability measurement of administration quality had a positive association with consumer loyalty, demonstrating that an expansion in one will prompt an expansion in the other.

\section{REFERENCES}

1) BharthVajan R., Ramachandran S.,Psychographic dimensions of training,2016,International Journal of Pharmacy and Technology,V-8,I-4,P-23727-23729

2) Balakrishnan P., Bharthvajan R.,A study on human resource planning in hospitals in Chennai City,2014,International Journal of Applied Engineering Research,V-9,I-22,P-7503-7507

3) Priyadarsini P., Bharthvajan R.,Role of emotional intelligence training programme in reducing the stress of the nurses,2014,International Journal of Applied Engineering Research,V-9,I-22,P-7411-7421 
4) Kerinab Beenu G., Bharthvajan R.,Empirical analysis on the cosmetic buying behavior of young women in South India,2014,International Journal of Applied Engineering Research,V-9,I-22,P-7361-7366

5) Balakrishnan P., Bharthvajan R.,Whistling in the wind,2014,International Journal of Applied Engineering Research,V-9,I-22,P-7586-7593

6) Krishnan B., Peter M.,Health hazards of Indian Bpo employee-an alarming issue,2014,International Journal of Applied Engineering Research,V-9,I-22,P-7336-7341

7) Kerinab Beenu G.H., Peter M.,Role of insurance in economic development,2014,International Journal of Applied Engineering Research,V-9,I-22,P-7532-7539

8) Balakrishnan P., Peter M., Priyadarsini P.,Efficiency of safety measures for wellbeing of employees in manufacturing industry,2014,International Journal of Applied Engineering Research,V-9,I-22,P-7376-7382

9) Anbarasi M., Praveen Kumar S.,Online sales promotions of herbal products and its effectiveness towards tanisha.com,2019,Indian Journal of Public Health Research and Development,V-10,I-1,P-195-200

10) Anbarasi M., Praveen Kumar S., Various online marketing and promotions strategies to improve the validation towards the organic products in the pharmaceutical sectors,2019,Indian Journal of Public Health Research and Development, V-10,I-1,P-263-269

11) Loganathan R., Praveen Kumar S.,Grievance handling a key factor for solving issues of employees in an organization,2014,International Journal of Applied Engineering Research,V-9,I-22,P-7483-7491

12) Loganathan R., Praveen Kumar S.,Study on preference of private label brands in super and Hypermarkets,2014,International Journal of Applied Engineering Research,V-9,I-22,P-7327-7335

13) Smitha M., Praveen Kumar S.,Understanding stress and its managementamong the nurses in Chennai city,2014,International Journal of Applied Engineering Research,V-9,I-22,P-7560-7565

14) Kerinab Beenu G.H., Praveen Kumar S.,A study on the investment behavior of Chennai investors in mutual fund schemes,2014,International Journal of Applied Engineering Research,V-9,I-22,P-7520-7525

15) Loganathan R., Praveen Kumar S.,Retention strategies key for organizational productivity,2014,International Journal of Applied Engineering Research,V-9,I-22,P-7443-7447

16) Pavithra J., Ganesan M., Brindha G.,State wise analysis of microfinance sector in India,2016,International Journal of Pharmacy and Technology,V-8,I-4,P-23417-23432

17) Pavithra J., Ganesan M.,A comparative study on microfinance in India and abroad,2016,International Journal of Applied Business and Economic Research,V-14,I-8,P-5471-5476

18) Pavithra J., Ganesan M.,A study on awareness and impact of micro-financial schemes,2016,International Journal of Applied Business and Economic Research,V-14,I-8,P-5449-5460

19) Senthilmurugan P., Pavithra J.,Consumer preference towards organised retailing with reference to Big Bazaar,2014,International Journal of Applied Engineering Research,V-9,I-22,P-7469-7475

20) Senthilmurugan P., Pavithra J.,Implication of social media marketing in growing healthcare industry,2014,International Journal of Applied Engineering Research,V-9,I-22,P-7448-7456

21) Loganathan R., Pavithra J.,Consumer perception towards private label brand over other brands in super markets and hypermarkets,2014,International Journal of Applied Engineering Research,V-9,I-22,P-7355-7360

22) Kerinab Beenu G., Pavithra J.,Tradeâ€"off between liquidity and profitability in logistics industry,2014,International Journal of Applied Engineering Research,V-9,I-22,P-7398-7401

23) Kerinab Beenu G., Pavithra J.,A study on the prospective consumerâ€ $\mathrm{TM}_{\mathrm{S}}$ perception towards utility cars in Chennai city,2014,International Journal of Applied Engineering Research,V-9,I-22,P-7526-7531

24) Pavithra J., Dilli Babu P., Ambuli T.V.,A study on budgetary control at Maruti Service Masters, Chennai,2014,International Journal of Applied Business and Economic Research,V-12,I-2,P-151-161

25) Pavithra J., Dilli Babu P., Ambuli T.V.,A study on customer satisfaction of retro Garments Pvt Ltd, Chennai,2014,International Journal of Applied Business and Economic Research,V-12,I-2,P-381-391

26) Kerinab Beenu G.H., Pavithra J., Senthilmurugan P.,A study on the influence of promotional activities for TATA ARIA among consumers in Chennai,2014,International Journal of Applied Engineering Research,V-9,I-22,P-7572-7578

27) Vijayaragavan S.P.,An investigative expert that's general FBG sensors, International Journal of Mechanical Engineering and Technology,V-8,I-8,PP-1500-1505,Y-2017

28) Vijayaragavan S.P.,Equalization routing protocol for Wi-Fi sensor strategy,International Journal of Mechanical Engineering and Technology,V-8,I-8,PP-1662-1666,Y-2017

29) Karthik B., Kiran Kumar T.V.U., Vijayaragavan P., Bharath Kumaran E.,Design of a digital PLL using 0.35 $\hat{\mathrm{I}}^{1 / 4 \mathrm{~m}}$ CMOS technology,Middle East Journal of Scientific Research,V-18,I-12,PP-1803-1806,Y-2013
30) Kanniga E., Selvaramarathnam K., Sundararajan M.,Kandigital bike operating system,Middle - East Journal of Scientific Research,V

31) Jasmin M., Vigneshwaran T., Beulah Hemalatha S.,Design of power aware on chip embedded memory based FSM encoding in FPGA,International Journal of Applied Engineering Research,V-10,I-2,PP-4487-4496,Y-2015

32) Jasmin M.,Optimization techniques for low power VLSI circuits,Middle East Journal of Scientific Research,V-20,I-9,PP-1082-1087,Y-2014

33) Jasmin M., Vigneswaran T.,Fuzzy controller for error control of on - Chip communication,2017 International Conference on Algorithms, Methodology, Models and Applications in Emerging Technologies, ICAMMAET 2017,V-2017-January,I-,PP-1-5,Y-2017

\section{AUTHORS PROFILE}

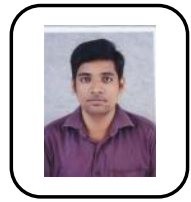

Gowtham Ashirvad Kumar Assistant Professor, Department of MBA, Bharath Institute of Higher Education and Research, Chennai, India.

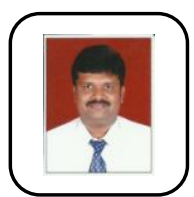

Dr. A. Ravi Kumar Associate Professor, Department of THM, Bharath Institute of Higher Education and Research, Chennai, India.

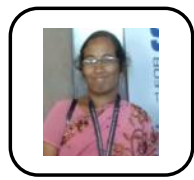

Ms J Pavithra Assistant Professor, Department of MBA, Bharath Institute of Higher Education and Research, Chennai, India. 